\title{
eWOM, Revisit Intention, Destination Trust and Gender
}

\begin{abstract}
This article investigates the impact of eWOM on intention to revisit and destination trust, and the moderating role of gender in medical tourism industry. Result from structural equation modeling $(n=240)$ suggests the following: (1) that eWOM influences intention to revisit and destination trust; (2) that destination trust influences intention to revisit; (3) that the impact of eWOM on intention to revisit is about 1.3 times higher in men; (4) that the impact of eWOM on destination trust is about 1.2 times higher in men; and (5) the impact of destination trust on the intention to revisit is about 2.3 times higher in women. Implications and future research directions are discussed.
\end{abstract}

Keywords: eWOM, Destination trust, intention to revisit, gender. 


\section{Introduction}

The med-tour industry is reported to be a multi-billion dollar one, it is expected to generate a market value of US $\$ 32.5$ billion by the end of 2019; and the current global med-tour market value was estimated to be around US $\$ 10.5$ billion (Globenewswire.com, 2015). Med-tourists engage in med-tour for several reasons, but the primary factor is the significant cost saving in the medical treatment. A substantial number of reports and empirical evidence have shown that med-tourists cost saving can range from 30 to 80 percent; but cautioned that these savings are contingent on the procedure and the country (Hall, 2011; Marlowe \& Sullivan, 2007; Nicolaides, 2012; Taylor, 2007; Yeoh et al., 2015). Furthermore, the presence of qualified medical personnel's in developing countries, long waiting list in home countries, availability in host countries, and the illegality of certain medical procedure contributes to the growth of med-tour (Keckley, 2008, Woodman, 2008).

The number of medical complications experienced by patients is underreported (Imison \& Schweinsberg, 2013), and the lack of reliable data related to the risk faced by med-tourists is critical (Whittaker, 2011; Woo, 2009). More specifically, this has led med-tourists to rely on personal information sources e.g., word-of-mouth (WOM) from friends, doctors, colleagues and the internet. Electronic word-of-mouth (eWOM) is a form written memo on the web usually posted by an experienced or previous consumer (Abubakar \& Ilkan, 2014); this memo may influence the behavioral actions of a potential consumer (Abubakar \& Ilkan, 2013). The empirical evidence provided above suggest that eWOM may influence medtourists intention to revisit and destination trust; this is primarily due to the intangible nature of med-tour services (Lin et al., 2009). Potential tourists consult their inner circles for travel related information (Casaló et al., 2015); which reduces the uncertainty and ambiguity (Bickart \& Schindler, 2001) associated with a med-tour destination.

Turkey has an estimated med-tour revenue of $\$ 1$ billion in 2015 (Anadolu Agency, 2015); and is the second largest country in the Eurasia in terms of med-tour revenue and arrivals (Beladi et al., 2015). The country has about 32 hospitals accredited by the Joint Commission International which are mostly located in Istanbul. About half a million med-tourists visits 
Turkey every year (Anadolu Agency, 2015; Ministry Of Health, 2012). These figures show that Turkey is an important player in the industry, and also highlight the importance and reputation of the sector in the country. Policy makers in key med-tour hubs (e.g., Turkey) are interested in increasing revenues. For instance, Turkey's Ministry of Health plans to increase the number of med-tourists to about 2 million by 2023, by introducing tax-free health care zones specifically tailored for foreign patients (Anadolu Agency, 2015). This can be achieved by delivering top-notch services and the assurance of patient safety.

Empirical evidence showed that online reviews have significant influence on destination image (e.g., Govers \& Go, 2004; Mridula, 2009), destination choice (Jalilvand \& Samiei, 2012b) and revisit intention (e.g., Kim et al., 2012; Quintal \& Polczynski, 2010) of tourists. The impact of gender on shopping intents has been a subject of special interest to researchers for a long time. A handful of studies noted that men and women have different attitudes toward online messages and shopping (Chen et al., 2015; Slyke et al., 2010). With the exception of Abubakar (2016) and Abubakar and Ilkan (2016), empirical work that investigates the impact of eWOM on revisit intention and destination trust coupled with gender in the med-tour industry is sparse.

Moreover, the aforementioned studies were with potential tourists at home country. In contrast to the ideal-typical approach, we propose that revisit intention should be captured at destination point with actual tourists. This approach has been adopted by prior revisit intention studies (Guntoro \& Hui 2013; Marinkovic et al. 2014). To bridge the gap in the eWOM, intention to revisit, destination trust and gender literature, this study offers an integrated approach to examine the interplay of the aforementioned variables. It is important to say that this is the first study that integrates these four variables together in a unique model of tourism behavior in the virtual world. Figure 1 presents the conceptual model of the study. 


\section{Literature review}

Much has been debated, written and published about the reason med-tourists travel over international borders, these motives varies significantly by country or region. For instance Indonesians often travel to Singapore for improved healthcare services (Gan \& Frederick, 2011), high cost for Americans (Horowitz \& Rosensweig, 2008), and long waiting list for Europeans (Bies \& Zhacharia, 2007). According to Westbrook (1987) WOM is "informal communications directed at other consumers about the ownership, usage, or characteristics of particular goods and services and/or their sellers". WOM has now taken a different form known as the eWOM, which resides in the virtual server (Minxue, et al. 2011). Abubakar (2012) noted that eWOM is an addendum to the classic interpersonal communications in the contemporary world.

eWOM's are positive or negative statements made by consumers concerning products or services that are scripted and posted on the internet for individuals and institutions (HennigThurau et al., 2004, p. 39). The increased literacy on the use of computer and the internet has made modern consumers savvy since they can collect, gather, analyze, interpret, and disseminate information related to a product or service (Chevalier \& Mayzlin, 2006). Besides, traditional advertisement is losing its place in the eyes of consumers, because they view it as a medium by which companies exploit them. As such, they have little regard for the classic advertisement approach. This development has called for more research and modification to marketing strategies of various firms (Rowley, 2001).

Research has shown that the Internet has facilitates web-based searches for med-tour related information (Frederick \& Gan, 2015). For instance, empirical evidence has shown that $80 \%$ of American internet users had searched for medical related information, $56 \%$ had searched for information relating to treatment; $44 \%$ and $36 \%$ of them had searched for information regarding physicians and healthcare centers respectively (Pew Research Center, 2011). In addition, websites and online communities are the main channel used by the medtour marketers to attract med-tourist (Frederick \& Gan, 2015; Lunt et al., 2010). 


\section{eWOM}

Park and Lee (2009) suggested that eWOM has higher effect when a good is consumed than when it is searched, fundamentally suggesting that the impact of eWOM becomes stronger after service encounter, this position was shared by Gruen, Osmonbekov, \& Czaplewski, (2006) as they suggested that eWOM leads to post-purchase customer loyalty. As against the traditional WOM communication, eWOM eliminate the negativity associated with bias information dissemination among friends, relatives and family because the identity of the reviewer cannot be identified (Abubakar, Ilkan, \& Sahin, 2016). Different motivations has been found to be responsible for generating eWOM, pre-purchase expectations, customer delight, satisfaction or dissatisfaction and general consumer behaviors. The credibility and reliability of eWOM has also be studied. eWOM being a form of online reviews serves as medium to help other consumer; vacationer make good decision(Bronner \& de Hoog, 2011). These characteristics of eWOM present a desirable purpose to investigate how eWOM impacts med-tourists' destination trust and intention to revisit.

\section{Destination Trust.}

Due to the simultaneous nature of production and consumption of tourism products, destination marketers must ensure delivery of promised service during advertisement and promotion. The integrity and transparency of service offerings of a destination results in the trust that tourist develops for such destinations. Evidence from Oh (2002) provide support for trust as an antecedent of repeat visit. Yet while research across the tourism industry recognize that destination image and trust operates through WOM and eWOM to constitute travel intention (Abubakar, \& Ilkan, 2016), the details of this argument in respect to revisit intention remain underdeveloped.

\section{Intention to visit/ Intention to Revisit.}

Consumer of tourism services are often made up of two classes. The initial consumer and the returning consumer(Huang \& Hsu, 2009). Decision making for first time consumer are mostly based on information gathered from various source which results in an expectation of a desired encounter from a tourism service provider. This expectation has been studied in the hospitality literature as intention to visit. The literature target prospective consumer behavior and investigate the effect of different predictors in their decision making process. Revisit intention however, target repeat consumers of tourism services whom had 
previously encounter the actual delivery of the service. Most studied has predicted revisit intention has an extension of satisfaction derived from initial encounter (Huang \& Hsu, 2009; Um et al., 2006). This study intend to extend the literature by established the predictive effect of eWOM on revisit intention.

\section{Research Hypotheses}

\section{1. eWOM and Intention to Revisit}

Intention to revisit is the willingness to visit a destination again. Destination marketers are interested in understanding the drivers of tourist intention to revisit, because the cost of retaining re-visitors is much less than the cost of attracting new visitors (Um et al., 2006). eWOM communication has received huge attention in the recent years, due to its impact on marketing strategy (Smith et al., 2007). Moreover, patients are now more proactive and the main sources of their marketing intelligence include personal experience, eWOM, and advertisements (Yang, 2011). Research has shown that favorable online reviews concerning a hotel increase the likelihood of booking and room sales (e.g., Duverger, 2013; Mauri \& Minazzi, 2013; Ogut \& Tas, 2012; Ye et al., 2011). Whereas minimizing negative eWOM is expected to ensure re-patronage of the establishment (Ko \& Kim, 2011). More specifically, empirical evidence in hotel and travel industry suggested that eWOM can influence tourists travel and/or revisit intention (e.g., Filieri, 2015; Filieri \& McLeay, 2014; Sparks \& Browning, 2011; Vermeulen \& Seegers, 2009; Ye et al., 2009; Arsal et al., 2008). This article argues that eWOM should equally have influence on revisit intention in the med-tour industry. Thus, the following hypothesis was proposed.

H1: eWOM has a significant impact on the intention to revisit in the medical tourism context.

\section{2. eWOM and Destination Trust}

Destination trust refers to a visitor's willingness to rely on the ability of a destination to perform its advertised functions. In other words assuring tourists that service provision will be transparent, reliable, risk, and hassle free (Abubakar \& Ilkan, 2016). Potential tourists were more likely to seek information about a destination from friends, colleagues and 
relatives who had experience with the destination (Lee et al., 2007). This is because WOM messages comfort customers, reduce fear and uncertainty, and enact assurance (Martilla, 1971). Settle and Alreck (1989) and Murray's (1991) added that WOM messages are primary uncertainty eliminator for risks and uncertainty accrued from the potential purchase of a product or service. The inherent impact of eWOM on consumers' behavioral intentions can be more powerful than the traditional WOM (EunHa \& Soocheong, 2011). Because eWOM communication is more reliable than WOM due to its anonymous nature, and the absence of incentives. Wu and Wang (2011) suggested that there is a linkage between eWOM, brand trust and purchase intention, thus the direction of eWOM will increase or decrease the impact of trust on purchase intents (Long-Yi \& Ching-Yuh, 2010). A careful examination of the above findings reveal that there is a potential relationship between eWOM and destination trust. This paper posits that positive eWOM messages will eliminate uncertainty, and enhance destination trust. Thus, the following hypothesis was proposed.

H2: eWOM has a significant impact on destination trust in the medical tourism context.

\subsection{Destination Trust and Intention to Revisit}

Brand trust evoke consumers' emotional attachment toward a brand (Esch et al., 2006). Lin and $\mathrm{Lu}(2010)$ suggested that trust has a significant impact on purchase intention when positive WOM is high. There is a broad consensus among scholars that trust serve as an effective means for minimizing uncertainty (e.g., Han \& Hyun, 2013; Pavlou et al., 2007). For instance, Chiu et al. (2012) revealed that customer levels of trust can influence repurchase intention. Similarly, destination trust may evoke med-tourist's emotional attachment toward a destination, and such attachment can predict the willingness of consumers to make financial sacrifices in order to obtain it (Thomson et al., 2005). Research has shown that tourists are more likely to visit destinations that they perceive as trustworthy and dependable (Roodurmun \& Juwaheer, 2010; Ekinci \& Hosany, 2006). Furthermore, Han (2013) indicated that trust is particularly significant in a med-tour context such that malpractice, low-quality medical care, and medical accidents are increasingly fretted-over risks. Med-tourists are more likely to revisit when they trust the healthcare establishment as noted by Han \& Hyun (2015). Thus, the following hypothesis was proposed. 
H3: Destination trust has a significant impact on the intention to revisit in the medical tourism context.

\subsection{Gender Role}

A substantial body of researches have supported the hypothesis that women and men respond to and express risk differently (e.g., Palich \& Bagby, 1995; Simon et al., 2000; Brindley, 2005; Eckel \& Grossman, 2008). Social role theory posits that gender differences in social behaviors originate from shared expectations about what is appropriate behavior for men and women (Karakowsky, \& Elangovan, 2001). Risk expression varies across genders, primarily due to gender identity, which is isomorphic. For example, most men holds a masculine agnatic identity, and most females holds a feminine communal identity (MeyersLevy \& Loken, 2015). While risk perception is the manner people of the same gender assess risk in a rational way, and weighing information before making a decision. A number of studies have supported the notion that women have higher risk perception and/or are riskaverse than men (e.g., Byrnes et al., 1999; Hudgens \& Fatkins, 1985; Pascual-Miguel, 2015; Van Slyke et al., 2002). While others asserted that women are more trusting than men (Feingold, 1994).

The traditional role in taking responsibility for the family in that "putting the family's resources in danger, especially in a situation of necessity, tends to increase women's risk perception and tolerance" (Langowitz \& Minniti, 2007, p. 356). Men and women differs on several dimensions in the cyber world; and these differences may arise from social, cultural, psychological, and other environmental factors (Meyers-Levy \& Loken, 2015). Men differ from women with respect to eWOM messages and shopping behaviors (e.g., Rodgers \& Harris, 2003, Dittmar et al, 2004). For instance, Olsen and Cox (2001) stated that in the presences of social and technological hazards, women are more risk-averse (i.e. less risktaking) than men, even when the level of expertise and experience is the same (e.g., Powell \& Ansic, 1997; Dwyer et al., 2002; Harris et al., 2006). Thus, the following hypothesis was proposed

H4: The strength of the relationship between eWOM, destination trust, and revisit intention will differ by gender in the medical tourism context. 
Insert Figure 1: Conceptual model

\section{Methodology}

Turkey as a medical destination has about 32 international accredited hospitals; the country offers top-notch medical services in various areas e.g., cardiology, endocrinology, nephrology, oncology, neurology, dermatology, gynecology/obstetrics, orthopedics, hair transplantation and others (Skylife, 2011). Some hospitals have partnerships with top American hospitals such as Harvard Medical Center and Johns Hopkins, and are staffed with many highly skilled, English speaking, and western trained doctor (Foreign Economic Relation Board, 2012; Organization of Medical Tourism, 2015). One of these hospitals (Acibadem Health Group) is declared among "ten hospitals worth to trip" in the world forbes.com (Van Dusen, 2007). Cultural factors, language and social ties may influence medtourist decision but referral is the most important factor (Hanefeld et al., 2015); and referral is a form of eWOM.

\subsection{Sampling and procedure}

Data were obtained from med-tourists in Istanbul, using a convenient sampling technique. This sampling technique was employed because of subjects' accessibility and proximity to the researchers. Data obtained were analyzed using SPSS and AMOS version 21 to estimate the proposed structural model. We initially contacted the 10 certified Med-tour hospitals and establishment for permission to conduct the study. These hospitals were selected for the study due to their high participating in medical tourism and high number of Med-tourist participation. Four out of ten agreed and granted permission to conduct the study. We then proceed by sending 100 questionnaires to each of the 4 participating hospitals together with cover letter detailing the purpose of the study, assurance of anonymity, confidentiality and return envelope for each respondent (Podsakoff et al., 2003).

The questionnaires were administered to the Med-tourists through their attending nurses whom have been briefed about the study through the Human resource unit of the participating hospitals; 350 questionnaires were initially returned accounting for $87.5 \%$ 
response rate. However, after careful screening using the five inclusion criteria of: (1) 18 years of age or older; (2) fluent in English and/or Turkish; (3) foreign nationals; (4) A member of any online community; (5) read or post online reviews, we have 240 final useable sample. The screening was done to allow the selection of med-tourists who have used online reviews to make travel decisions following Abubakar and Ilkan, (2016)'s procedures. All data were collected in total of 8 weeks.

$59 \%$ of our final sample were married. $38 \%$ were between 31 and 40 years old, $37 \%$ were between 41 and 50 years old, 14\% were above 50 years old and the rest were between 21 and 30 years old. Forty one percent of the respondents have monthly income over 4000 Turkish Lira; (37\%) have monthly between 3000 and 3999 Turkish Lira, and (16\%) have monthly income between 2000 and 2999 Turkish Lira; and the rest have less than 2000 Turkish Lira. In terms of education, (34\%) of the respondents have attended some college; (33\%) have bachelor degrees; (22\%) have higher degrees; and the rest have high school diplomas. The demographic breakdown of the med-tourists nationality is as follows: From Azerbaijan (17\%); Germany (15\%); Bulgaria (14\%); Iraq (13\%); Libya (12\%); Romania (11.6\%); England (8\%); Holland (4\%); USA (3\%); Russia (2\%) and (1\%) from Northern Cyprus.

\subsection{Measures}

Although Turkish is the official language in Turkey, we administered the survey in English and Turkish. This is because the respondents are foreigners visiting Turkey for purpose of medical tourism.

\subsection{1 eWOM}

We adapted 6- item scale used by prior studies (Jalilvand \& Samiei, 2012a; Abubakar, Ilkan, \& Sahin, 2016). A sample item for eWOM was: “If I don't read tourists' online travel reviews when I travel to a medical destination, I worry about my decision". For this measure, response range from 5 (strongly agree) to 1 (strongly disagree). All factor loadings for this construct were beyond the threshold level of 0.5 . 


\subsubsection{Destination trust}

We measured destination trust with 8-item scale used by prior study in med-tourism context (Abubakar \& Ilkan, 2016). A sample item was: "Turkish hospitals would be honest and sincere in addressing my concerns". For this measure, response range from 5 (strongly agree) to 1 (strongly disagree). All factor loadings for this construct were beyond the threshold level of 0.5 .

\subsubsection{Intention to revisit}

We used 3-item scale developed by Blodgett, Hill, \& Tax, (1997) and used in prior study by (Kim et al., 2013). A sample item was: "It is very likely that I will revisit a hospital in Turkey". All factor loadings for this construct were beyond the threshold level of 0.5.

\subsubsection{Gender}

The moderating effect of gender on the predictive capability of eWOM of the mediated relationship of destination trust on med-tourists' intention to revisit was studied in this research, hence we report that $53 \%$ of our final sample (240) were female and the others male.

\section{Findings}

Because we used self-reported data collection design, we perform confirmatory factor analysis to validate the discriminant nature of our construct. The model fit indices were assessed twice, similar to the approach carried out by Morgan, Kaleka and Katsikeas (2004). First, a single factor model was tested, in this model all the research variables were loaded into a single factor. The single factor model failed to fit the data satisfactorily, the goodnessof-fit for the model yielded ( $\left.\mathrm{X}^{2}=3213.07, \mathrm{df}=104, \mathrm{p}=.000\right),(\mathrm{GFI}=.40,1=$ maximum fit), $(\mathrm{NFI}=.59,1=$ maximum fit $),(\mathrm{CFI}=.60,1=$ maximum fit $),(\mathrm{RMSEA}=.35$, values $<.08$ indicating good fit), (CMIN/DF $=30.89$, values $>1$ and $<3$ are accepted). Next, a three factor (proposed) model was tested, the model fit the data satisfactory, and the goodness-of-fit for the model yielded $\left(\mathrm{X}^{2}=131.7, \mathrm{df}=110, \mathrm{p}=.08\right),(\mathrm{GFI}=.90,1=$ maximum fit $),(\mathrm{NFI}=.94,1=$ 
maximum fit), (CFI = .99, $1=$ maximum fit), (RMSEA $=.040$, values $<.08$ indicating good fit), (CMIN/DF $=1.20$, values $>1$ and $<3$ are accepted).

The result showed that the proposed model fits were reasonable and acceptable. All factors and items load significantly on designated constructs, and there is no evidence of any cross loading except one item for destination trust (Fornell \& Larcker 1981). The factor loadings were all above the benchmark value .50, composite reliability (CR) were above the benchmark value .60; similarly average variance extracted (AVE) values were also above cutoff point .50 (Hair, Anderson, Tatham, \& Black, 1998). Overall, this provide evidence of internal consistency, convergent and discriminant validity (Bentler, \& Bonett, 1980; Bollen, 1989a, 1989b; Jöreskog, \& Sörbom, 1984; Tanaka, \& Huba, 1985). In addition, the outcome provided collateral evidence to that common method bias seems not to be a problem. See Table 1 and 2.

Insert TABLE 1: Psychometrics Properties of the Measures $(n=240)$

Insert TABLE 2: Means, standard deviations (SD), and correlations of study variables

The empirical results from the structural model suggests that eWOM positively influences intention to revisit $(\mathrm{r}=.338, p=.000)(\beta=.296, \mathrm{t}=4.42, p=.000)$; and eWOM explains $R^{2}$ (intention to revisit) $=10 \%$ of the variance [H1 gained support]. eWOM positively influences destination trust $(\mathrm{r}=.312, p=.000) .(\beta=.332, \mathrm{t}=5.08, p=.000)$; and eWOM explains $R^{2}$ (destination trust) $=11.4 \%$ of the variance [H2 gained support]. Destination trust influences intention to revisit $(\mathrm{r}=.277, p=.000)(\beta=.190, \mathrm{t}=3.02, p=.000)$; and destination trust explains $R^{2}$ (intention to revisit) $=8 \%$ of the variance [H3 gained support]. See table 2 and 3 .

\section{Insert TABLE 3: Maximum likelihood estimates for the research model $(n=240)$}

Table 4 present total, direct and indirect estimates of the study variables. Although not hypothesized, this paper evaluated the mediating effect of destination trust with the aid of bootstrapping analysis $(n=2000)$ as suggested by (Preacher \& Hayes, 2004). A bias-corrected 
bootstrap indicated that the indirect effect of eWOM on intention to revisit through destination trust was significant 0.059 ( $p=.010,95 \%$ confidence interval: $0.020-0.121$ ). See table 4.

Insert TABLE 4: Standardized break down of the total effect of the research model $(n=240)$

The paper hypothesized that the strength of the relationship between eWOM, destination trust, and revisit intention will differ by gender in the med-tour context. The dataset was split into two, and the hypothesized relationships were assessed gender wise. Table 5 suggests that the impact of eWOM on intention to revisit is about 1.3 times higher in men; the impact of eWOM on destination trust is about 1.2 times higher in men; and the impact of destination trust on the intention to revisit is about 2.3 times higher in women. [H4 gained support].

Insert TABLE 5: Multi-group moderation analysis $(n=240)$

\section{Discussion and Conclusion}

This paper builds on previous research by exploring the contribution of social influence on destination trust and intention to revisit from med-tour angle. This study investigated how eWOM may enhance destination trust and intention to revisit a medical hub. The structural equation modeling suggests that eWOM positively influences intention to revisit, consistent with prior studies in travel and leisure tourism (Vermeulen, \& Seegers, 2009; Filieri \& McLeay, 2014). This outcome underlined the significant influence of eWOM on important variable in the tourism industry, more specifically med-tour industry. Second, eWOM positively influences destination trust; this also complement other scholars who asserted that eWOM has significant influence on destination image (Jalilvand et al., 2012), and destination choice (Jalilvand \& Samiei, 2012b). The result provide a deeper and richer portrait of the relationship between eWOM and destination trust. Third, destination trust influences intention to revisit, this findings is also consistent with the research prediction. Similarly, prior studies have also shown that destination image has an impact on the 
intention to revisit (Jalilvand et al., 2012; Kim et al., 2012). As such, the present study is thus a compelling extension of the previous research concerning the antecedents of intention to revisit. The core practical and theoretical contribution of the present study is the extension of the above said variables to med-tour industry.

Consistent with prior research, this study found that men are more trusting than women; the result revealed significant variance between men and women. The impact of eWOM on intention to revisit is about 1.3 times higher in men; in line with social role theory proposition which classified men as agnatic and competent (Eagly, 1987; Eagly \& Wood, 1991). The theory and the current finding suggests that men are more likely to revisit a destination when the volume of positive eWOM is high. The impact of eWOM on destination trust is about 1.2 times higher in men; this is because men use online information to explore and discover new things (Taylor et al., 2011). This finding suggests that logically, travel is an inclusive category. Finally, the impact of destination trust on the intention to revisit is about 2.3 times higher in women, which also conforms to the existing hypothesis: women are more risk-averse. This outcome shows that when women trust a particular destination, their intention to revisit tends to be higher than men; this is primarily due to their communal nature, in line with social role theory (Eagly \& Wood, 1991; Karakowsky, \& Elangovan, 2001).

The context of this research has important implications for med-tour destination marketers, the results suggest that practitioners have a lot to gain from computerized information tools. Segmenting med-tourists on gender basis may produce a more sensitive instrument which destination marketers can use to increase destination trust and intention to revisit through eWOM messages. Practitioners at medical clinics and destination countries must recognize the intricate and essential role of eWOM; and utilize it in developing strategies to acquire and retain med-tourists, and to maximize revenue. This paper recommends that med-tour hubs should improve their amenities and services such that they will resemble excellent hotels (Bernstein, 2012; Hume \& DeMicco, 2007). Due to the fact that top-notch service experience can induce positive eWOM, which in turn facilitates indirect destination branding co-creation due to the interactive and diffusive nature of eWOM. 
Two, this paper recommends that med-tour hubs should furnish their websites to have interactive features, such as real-time interaction with previous med-tourists who agree to respond to and share their contact details with potential med-tourists. This may be a good strategy to penetrate other untapped markets. Third, the paper advises med-tour hubs to change their business orientation from transaction to relationship, from tourists into partners, and from long-term relationship into commitments as suggested by (Raju et al., 1995). On the negative front, theory of negativity suggests that negative eWOM is easily absorb by tourists than positive eWOM; therefore, negative eWOM can have a stronger negative influence on travel and revisit intention. On the positive front, the cost of attracting new tourists is five times higher than retaining existing tourists (Yeoh et al., 2015) and "a $5 \%$ decrease in the customer defection rate can boost profits from $25 \%$ to 95\%" (Jacob, 1994). Marketers should develop diverse benefits that encourage the spread of positive eWOM to acquire new med-tourists and for repeat med-tourists to re-patronage their services.

\subsection{Limitation and Future Study}

While this paper has shed some light on eWOM literature, it has some limitations. The nature of the research design e.g. sample size, data collection method, potentiality of causal inference, and the absences of experimental control establish causality. The response rate was somewhat low, which may limit the generalizability of the model. However, the results from a bias-corrected bootstrap indicated that sample size was not a problem. As this research utilized samples with a single country focus, future research should examine the generalizability of these findings via cross-cultural studies. A similar model can be tested in other tourism industry to augment the current finding e.g. geo-tourism, educational tourism and others. Finally, the effect of eWOM on destination trust and image simultaneously, and behavioral outcomes like vacation satisfaction, intention to travel and intention to revisit can be investigated. 


\section{REFERENCE}

Abubakar, A.M. (2012) Impact of IT on business: eWOM and the Three W's (Who, Why, and What). Eastern Mediterranean University. Dissertations and Theses.

Abubakar, A.M., \& Ilkan, M. (2013) More Adverts or More eWOM's. Journal of Business \& Financial Affairs 2:129.

Abubakar, A.M., \& Ilkan, M. (2014) eWOM and the 3W's Who, Why and What. LAP LAMBERT Academic Publishing, Morebooks. Germany.

Abubakar, A. M. (2016). Does eWOM influence destination trust and travel intention: A medical tourism perspective. Economic Research-Ekonomska Istraživanja, 29(1), 598-611.

Abubakar, A. M., \& Ilkan, M. (2016). Impact of online WOM on destination trust and intention to travel: A medical tourism perspective. Journal of Destination Marketing \& Management, http://dx.doi.org/10.1016/j.jdmm.2015.12.005.

Abubakar, A. M., Ilkan, M., \& Sahin, P. (2016). eWOM, eReferral and Gender in the Virtual Community. Marketing Intelligence and Planning. http://dx.doi.org/10.1108/MIP-05-20150090

Anadolu Agency. (2015). Turkey sees rise in medical tourism. Available at: http://www.hurriyetdailynews.com/turkey-sees-rise-in-medicaltourism--.aspx?pageID=238\&nID=80466\&NewsCatID=349 (Accessed 20 August, 2015)

Arsal, I., Backman, S., \& Baldwin, E. (2008). Influence of an online travel community on travel decisions. In P. O'Connor, W. H€opken, \& U. Gretzel (Eds.), Information and communication technologies in tourism 2008, (pp. 82-93). Vienna, Austria: Springer-Verlag.

Bambauer-Sachse, S., \& Mangold, S. (2011). Brand equity dilution through negative online word-of-mouth communication. Journal of Retailing and Consumer Services, 18(1), 38-45.

Beladi, H., Chao, C., Shan Ee, M., \& Hollas, D. (2015). Medical tourism and health worker migration in developing countries, Economic Modeling, 46,391-396

Bentler, P.M., \& Bonett, D.G. (1980). Significance tests and goodness of fit in the analysis of covariance structures. Psychological Bulletin, 88(3), 588-606.

Bernstein, N. (2012). Chefs, butlers, marble baths: Hospitals vie for the affluent. The New York Times. Available at: http://www.nytimes.com/2012/01/22/nyregion/chefs-butlersand-marble-baths-not-youraveragehospitalroom.html?pagewanted $1 / 41 \&$ r $1 / 43 \& \mathrm{ref}^{1} 1 / 4$ general\&src $1 / 4$ me\& 9 (Accessed March 15, 2013) 
Bickart, B., \& Schindler, R.M. (2001). Internet forums as influential sources of consumer information. Journal of Interactive Marketing, 15(3), 31-40.

Bies, W., \& Zacharia, L. (2007). Medical tourism: Outsourcing surgery. Mathematical and Computer Modelling, 46, 1144-1159.

Blodgett, J. G., Hill, D. J., \& Tax, S. S. (1997). The effects of distributive, procedural, and interactional justice on post-complaint behavior. Journal of Retailing, 73(2), 185-210.

Bollen, K.A. (1989a). Structural equations with latent variables. New York: Wiley.

Bollen, K.A. (1989b). A new incremental fit index for general structural equation models. Sociological Methods and Research, 17, 303-316.

Brindley, C. (2005). Barriers to women achieving their entrepreneurial potential: women and risk. International Journal of Entrepreneurial Behavior \& Research, 11(2), 144-161.

Bronner, F., \& de Hoog, R. (2011). Vacationers and eWOM: Who Posts, and Why, Where, and What? Journal of Travel Research, 50(1), 15-26.

Byrnes, J.P., Miller, D.C., \& Schafer, W.D. (1999). Gender differences in risk-taking: a metaanalysis. Psychological Bulletin, 125(3), 367-38.

Casaló, L.V., Flavián, C., Guinalíu, M. \& Ekinci, Y. (2015), Do online hotel rating schemes influence booking behaviors? International Journal of Hospitality Management, 49, 28-36.

Chen, Y., Yan, X., Fan, W., \& Gordon, M. (2015). The joint moderating role of trust propensity and gender on consumers' online shopping behavior. Computers in Human Behavior, 43, 272283.

Chevalier, J. A., \& Mayzlin, D. (2006). The effect of word of mouth on sales: Online book reviews. Journal of Marketing Research, 43(3), 345-54

Chiu, C., Hsu, M., Lai, H., \& Chang, C. (2012). Re-examining the influence of trust on online repeat purchase intention: The moderating role of habit and its antecedents. Decision Support Systems, 53(4), 835-845

Cohen, I.G., 2010. Protecting patients with passports: medical tourism and the patient protective-argument. Iowa Law Review, 95(5), 1467-1567.

Delgado-Ballester, E. (2004). Applicability of a brand trust scale across product categories: A multi-group invariance analysis. European Journal of Marketing, 38(5/6), 573-592.

Dittmar, H., Long, K., \& Meek, R. (2004). Buying on the Internet: Gender differences in on-line and conventional buying motivations. Sex Roles, 50(5), 423-444. 
Duverger, P. (2013). Curvilinear effects of user-generated content on hotels' market share: A dynamic panel-data analysis. Journal of Travel Research, 52, 465-478.

Dwyer, P. D., Gilkeson, J. H., \& List, J. A. (2002). Gender differences in revealed risk-taking: evidence from mutual fund investors. Economic Letters, 76(2), 151-158

Eagly, A. H. (1987). Sex differences in social behavior: A social-role interpretation L. Erlbaum Associates, Hillsdale, NJ.

Eagly, A. H., \& Wood, W. (1991). Explaining sex differences in social behavior: A metaanalytic perspective. Personality and Social Psychology Bulletin, 17(3), 306-315.

Eckel, C. C., \& Grossman, P. J. (2008). Men, women and risk aversion: experimental evidence. Handbook of Experimental Economic Results, 1(1), 1061-1073.

Ekinci, Y., \& Hosany, S. (2006). Destination personality: an application of brand personality to tourism destination. Journal of Travel Research, 45, 127-139.

Esch, F.R., Langner, T., Schmitt, B. H., \& Geus, P. (2006). Are brands forever? How brand knowledge and relationships affect current and future purchases. Journal of Product \& Brand Management, 15, 98-105.

Eunha, J., \& Soocheong, J. (2011). Restaurant experiences triggering positive eWOM motivations. International Journal of Hospitality Management, 30(2), 356-366.

Feingold, A. (1994), Gender differences in variability in intellectual abilities: A cross-cultural perspective. Sex Roles, 30(1-2), 81-92

Filieri, R., \& McLeay, F. (2014). E-WOM and accommodation: an analysis of the factors that influence travelers' adoption of information from online reviews. Journal of Travel Research, 53(1), 44- 57.

Filieri, R. (2015). What makes online reviews helpful? A diagnosticity-adoption framework to explain informational and normative influences in e-WOM. Journal of Business Research, 68(6), 1261-1270.

Foreign Economic Relation Board (2012). Available at: http://www.healthinturkey.org/Upload/Document/document_SAIK\%20Flyer\%20English. pdf. (Accessed September 2013)

Fornell, C., \& Larcker, D. F. (1981). Evaluating Structural Equation Models with Unobservable Variables and Measurement Error. Journal of Marketing Research, 18, 39-50

Frederick, J.R. \& Gan, L.L. (2015). East-West differences among medical tourism facilitators' websites. Journal of Destination Marketing \& Management, 4(2), 98-109 
Gan, L.L., \& Frederick, J. R. (2011). Medical tourism in Singapore: A structure-conductperformance analysis. Journal of Asia-Pacific Business, 12(2), 1-30.

Globenewswire.com (2015). Medical tourism market will reach a market value of US $\$ 32.5$ billion by the end of 2019: Transparency Market Research. Available at: https://globenewswire.com/news-release/2015/05/27/739317/10136090/en/MedicalTourism-Market-will-Reach-a-Market-value-of-US-32-5-billion-by-the-end-of-2019Transparency-Market-Research.html (accessed March 2016)

Govers, R., \& Go, F.M. (2004). Projected destination image online: website content analysis of pictures and text. Information Technology and Tourism, 7(2), 73-89.

Gruen, T. W., Osmonbekov, T., \& Czaplewski, A. J. (2006). eWOM: The impact of customer-tocustomer online know-how exchange on customer value and loyalty. Journal of Business Research, 59(4), 449-456.

Guntoro, B., \& Hui, T. (2013), Travel Satisfaction and Revisit Intention of Chinese Visitors: The Case of Singapore, in Joseph S. Chen (ed.) Advances in Hospitality and Leisure (Advances in Hospitality and Leisure, Volume 9) Emerald Group Publishing Limited, 29 - 47.

Hair, J.F., Anderson, R.E., Tatham, R.L., \& Black, W.C. (1998). Multivariate Data Analysis, $5^{\text {th }}$ ed., Prentice Hall, Upper Saddle River, NJ

Hall, C. M. (2011). Health and medical tourism: A kill or cure for global public health? Tourism Review, 66(1/2), 4-15

Han, H. (2013). The healthcare hotel: distinctive attributes for international medical travelers. Tourism Management, 36, 257-268.

Han, H., \& Hyun, S. (2013). Image congruence and relationship quality in predicting switching intention: conspicuousness of product use as a moderator variable. Journal of Hospitality and Tourism Research, 37(3), 303-329.

Han, H., \& Hyun, S. (2015), Customer retention in the medical tourism industry: Impact of quality, satisfaction, trust, and price reasonableness. Tourism Management, 46, 20-29

Hanefeld, J., Lunt, N., Smith, R. \& Horsfall, D. (2015). Why do medical tourists travel to where they do? The role of networks in determining medical travel, Social Science \& Medicine, 124, 356-363.

Harris, C.R., Jenkins, M., \& Glaser, D. (2006). Gender differences in risk assessment: why do women take fewer risks than men? Judgment and Decision Making, 1(1), 48-63.

Hennig-Thurau, T., Gwinner, K. P., Walsh, G., \& Gremler, D. D. (2004). Electronic word-ofmouth via consumer-opinion platforms: What motivates consumers to articulate themselves on the internet? Journal of Interactive Marketing, 18(1), 38-52 
Hopkins, L., Labonté, R., Runnels, V., \& Packer, C. (2010). Medical tourism today: What is the state of existing knowledge? Journal of Public Health Policy, 31,185-198.

Horowitz, M. D., \& Rosensweig, J.A. (2008). Medical tourism vs. traditional international medical travel: A tale of two models. International Medical Travel Journal, 1-14. Available at: 〈http://www.imtj.com/articles/2008/medical-tourism-vs-traditional-internationalmedical-travel-a-tale-of-two-models/ $\rangle$. (Accessed January, 2010)

Huang, S., \& Hsu, C. H. C. (2009). Effects of Travel Motivation, Past Experience, Perceived Constraint, and Attitude on Revisit Intention. Journal of Travel Research, 48(1), 29-44.

Hudgens, G., \& Fatkins, L. (1985). Sex differences in risk-taking: repeated sessions on a computer simulated task. Journal of Psychology, 119(3), 1970-2206

Hume, L. F., \& DeMicco, F. J. (2007). Bringing hotels to healthcare: A Rx for success. Journal of Quality Assurance in Hospitality and Tourism, 8(1), 75-84.

Hunter, W. C. (2007). Medical tourism: A new global niche. International Journal of Tourism Science, 7(1), 129-140.

Imison, M., \& Schweinsberg, S. (2013). Australian news media framing of medical tourism in low- and middle-income countries: A content review. BMC Public Health, 13, 109

Jacob, R. (1994). Why some customers are more equal than other. Fortune, 130, 215-224.

Jalilvand, M. R., \& Samiei, N. (2012a). The effect of electronic word of mouth on brand image and purchase intention: An empirical study in the automobile industry in Iran. Marketing Intelligence \& Planning, 30(4), 460 - 476

Jalilvand, M. R., \& Samiei, N. (2012b). The impact of electronic word of mouth on a tourism destination choice. Internet Research, 22(5), 591-612.

Jalilvand, M. R., Samiei, N., Dini, B., \& Manzari, P. Y. (2012). Examining the structural relationships of electronic word of mouth, destination image, tourist attitude toward destination and travel intention: An integrated approach. Journal of Destination Marketing \& Management, 1(1), 134-143

Jöreskog, K. G., \& Sörbom, D. (1984). LISREL-VI user's guide (3rd ed.). Mooresville, IN: Scientific Software.

Karakowsky, L., \& Elangovan, A. R. (2001). Risky Decision Making in Mixed-Gender Teams: Whose Risk Tolerance Matters? Small Group Research, 32, 94-111.

Keckley, P. H. (2008). Medical tourism: Consumers in search of value. Washington, DC: Deloitte Centre for Health Solutions. 
Kim, K., Hallab, Z., \& Kim, J. N. (2012). The moderating effect of travel experience in a destination on the relationship between the destination image and the intention to revisit. Journal of Hospitality Marketing \& Management, 21(5), 486-505

Kim, H.J., Park, J., Kim, M., \& Ryu, K. (2013) Does perceived restaurant food healthiness matter? Its influence on value, satisfaction and revisit intentions in restaurant operations in South Korea, International Journal of Hospitality Management, 33, 397-405.

Ko, Y. K., \& Kim, B. J. (2011). The effects of switching cost perceived by patients and negative word of mouth on revisiting intention for hospital patients. Journal of Korean Academy of Nursing Administration, 17(1), 5-13.

Langowitz, N., \& Minniti, M. (2007). The Entrepreneurial propensity of women. Entrepreneurship Theory and Practice, 31, 341-364

Lee, J., Soutar, G., \& Daly, T. (2007). Tourists' search for different types of information: Across-nationality study. Information Technology and Tourism, 9 (3-4), 165-176

Lin, P., Jones, E. \& Westwood, S. (2009), Perceived Risk and Risk Relievers in Online Travel Purchase Intentions, Journal of Hospitality Marketing \& Management, Vol.18(8),pp.782-810

Lin, L., \& Lu, C. (2010). The influence of corporate image, relationship marketing, and trust on purchase intention: The moderating effects of word-of-mouth. Tourism Review, 65(3), 1634 .

Long-Yi, L., \& Ching-Yuh., L. (2010). The Influence of Corporate Image, Relationship Marketing, and Trust on Purchase Intention: The Moderating Effects of Word-of-Mouth. Tourism Review, 65 (3), 16-34

Lunt, N., Hardey, M., \& Mannion, R. (2010). Nip, tuck and click: Medical tourism and the emergence of web-based health information. The Open Medical Informatics Journal, 4, 1-11

Marinkovic, V., Senic, V., Ivkov, D., Dimitrovski, D., \& Bjelic, M. (2014). The antecedents of satisfaction and revisit intentions for full-service restaurants. Marketing Intelligence \& Planning, 32(3), 311 - 327.

Marlowe, J., \& Sullivan, P. (2007). Medical tourism: the ultimate outsourcing. Human Resource Planning, 30(2), 8-10.

Martilla, J. A. (1971). Word-of-mouth communication in the industrial adoption process. Journal of Marketing Research, 8(2), 173-8.

Mauri, A. G., \& Minazzi, R. (2013). Web reviews influence on expectations and purchasing intentions of hotel potential customers. International Journal of Hospitality Management, 34, 99-107 
Meyers-Levy, J., \& Loken, B. (2015), Revisiting gender differences: What we know and what lies ahead. Journal of Consumer Psychology, 25(1), 129-149.

Minxue, H., Fengyan, C., Alex S. L. T., \& Nan, Z. (2011). Making Your Online Voice Loud: The Critical Role of WOM Information. European Journal of Marketing, 45(7), 1277-1297.

Ministry of Health (2012). Evaluation report on medical tourism in Turkey, Directorate General of Health Services, Handbook.

Morgan. N. A, Kaleka, A. \& Katsikeas, C. S. (2004). Antecedents of export venture performance: A theoretical model and empirical assessment. Journal of Marketing, 68(1), 90108.

Mridula, D., (2009). Online destination image of India: A consumer based perspective. International Journal of Contemporary Hospitality Management, 21(2), 226-232.

Murray, K. B. (1991). A test of services marketing theory: Consumer information acquisition activities. Journal of Marketing, 55(1), 10-25.

Nicolaides, A. (2012). Lessons for South Africa from Asia on medical tourism's practice and potential. Medical Technology SA, 25(2), 7-16

Ogut, H., \& Tas, B. K. O. (2012). The influence of internet customer reviews on online sales and prices in hotel industry. The Service Industries Journal, 32(2), 197-214

Olsen, R.A., \& Cox, C.M. (2001). The influence of gender on the perception and response to investment risk: the case of professional investors. Journal of Psychology and Financial Markets, 2(1), 29-36

Organization of Medical Tourism (2015), Medical Tourism in Turkey. Available at: http://medicaltourism.com/Forms/Country/Turkey.aspx?cid=22 (Accessed 5 July 2015).

Palich, L. E., \& Bagby, D. R. (1995). Using cognitive theory to explain entrepreneurial risktaking: challenging conventional wisdom. Journal of Business Venturing, 10(3), 425-438.

Park, C., \& Lee, T. M. (2009). Information direction, website reputation and eWOM effect: A moderating role of product type. Journal of Business Research, 62(1), 61-67.

Pascual-Miguel, F.J., Agudo-Peregrina, A.F., \& Chaparro-Peláez, J. (2015) Influences of gender and product type on online purchasing. Journal of Business Research,

Pavlou, P. A., Liang, H., \& Xue, Y. (2007). Understanding and mitigating uncertainty in online exchange relationships: a principal-agent perspective. MIS Quarterly, 31, 105-136. 
Pew Research Center, (2011). Health Topics: 80\% of Internet users look for health information online. Available at: 〈http://www.pewinternet.org/media//Files/Reports/2011/PIP_Health_Topics.pdf〉. (Accessed November 13, 2013)

Podsakoff, P. M., MacKenzie, S. B., Lee, J. Y., \& Podsakoff, N. P. (2003). Common method biases in behavioral research: A critical review of the literature and recommended. Journal of Applied Psychology, 88(5), 879-903.

Powell, M., \& Ansic, D. (1997). Gender differences in risk behavior in financial decisionmaking: an experimental analysis. Journal of Economic Psychology, 18(6), 60-628.

Preacher, K. J., \& Hayes, A. F. (2004). SPSS and SAS procedures for estimating indirect effects in simple mediation models. Behavior Research Methods, Instruments, \& Computers, 36, 717731.

Quintal, V. A. \& Polczynski, A. (2010), Factors influencing tourists' revisit intentions. Asia Pacific journal of marketing and logistics, 22(4), 554-578.

Rahman, M. (2010). Outbound US medical tourism to selected Asian countries. International Journal of Behavioral and Healthcare Research, 2(1), 75-84.

Raju, P., Lonial, S., \& Gupta, Y. (1995). Market orientation and performance in the hospital industry. Journal of Health Care Marketing, 15(4), 34-41.

Rowley, J. (2001). Knowledge management in pursuit of learning: The learning with knowledge cycle. Journal of Information Science, 27(4), 227-237

Rodgers, S., \& Harris, M.A. (2003), Gender and e-commerce: An exploratory study. Journal of Advertising Research, 43(3), 322-329

Roodurmun, J., \& Juwaheer, T. D. (2010). Influence of trust on destination loyalty an empirical analysis the discussion of the research approach. International Research Symposium in Service Management, 1-23.

Settle, R. B. \& Alreck, P. L. (1989). Reducing buyers' sense of risk. Marketing Communications, 14(1), 34-40.

Simon, M., Houghton, S.M., \& Aquino, K. (2000). Cognitive biases, risk perception, and venture formation: How individuals decide to start companies. Journal of Business Venturing, 14(5), 113-134.

Skylife, (2011). Şifanın Merkezi Türkiye. Available at: http://www.turkishairlines.com/trtr/skylife/2011/nisan/makaleler/sifanin-merkezi-turkiye.aspx. (Accessed September 20, 2012). 
Slyke, C.V., Bélanger, F., Johnson, R.D., \& Hightower, R. (2010). Gender-based differences in consumer e-commerce adoption. Communications of the Association for Information Systems, $26,17-34$

Smith, T., Coyle, J., Lightfoot, E., \& Schott, A. (2007). Reconsidering models of influence: the relationship between consumer social networks and word-of-mouth effectiveness. Journal of Advertising Research, 47(4), 387-397.

Sparks, B. A., \& Browning, V. (2011). The impact of online reviews on hotel booking intentions and perception of trust. Tourism Management, 32(6), 1310-1323.

Tanaka, J.S. \& Huba, G.J. (1985). A fit index for covariance structure models under arbitrary GLS estimation. British Journal of Mathematical and Statistical Psychology, 38, 197-201.

Taylor, C. (2007). Medical tourism's popularity on the rise. Financial Times, 1.

Taylor, D. G., Lewin, J. E., \& Strutton, D. (2011). Friends, fans, and followers: Do ads work on social networks? Journal of Advertising Research, 51(1), 258-275.

Thomson, M., McInnis, D., \& Park, W. (2005). The ties that bind: measuring the strength of consumers' emotional attachment to brands. Journal of Consumer Psychology, 15, 77-91.

Travel Industry Association of America- TIA. (2005). Executive summaries-travelers' use of the internet, 2004 ed. Available at: http://www.tia.org/researchpubs/executive_summaries_travelers_use.htm (Accessed November, 2005).

Um, S., Chon, K., \& Ro, Y. H. (2006). Antecedents of revisit intention. Annals of Tourism Research, 33(4), 1141-1158.

Van Dusen, A. (2007). Ten hospitals worth to trip. Available at: http://www.forbes.com/2007/05/21/outsourcing-medical-tourism-bizcx_avd_0522medtourism_slide_4.html. (Accessed September 9, 2012).

Van Slyke., Comunale, C. L., \& Belanger, F. (2002). Gender differences in perceptions of webbased shopping. Communications of the ACM, 45(8), 82-86.

Vermeulen, I. E., \& Seegers, D. (2009). Tried and tested: the impact of online hotel reviews on consumer consideration. Tourism Management, 30(1), 123-7.

Vick, L. (2012). The perils of cosmetic surgery/medical tourism. Clinical Risk, 18,106-109

Westbrook, R. A. (1987). Product/consumption-based affective responses and post purchase process. Journal of Marketing Research, 24, 258-270. 
Whittaker, A. (2011). Cross-border assisted reproduction care in Asia: implications for access, equity and regulations. Reproduction Health Matters, 19, 107-116.

Woo, B.S. (2009). Medical tourism and the future of medical practice in Korea. Journal of Korean Medical Association, 52, 844-846.

Woodman, J. (2008). Patients beyond borders: Everybody's guide to affordable, world-class medical travel (2nd ed.). Chapel Hill, NC: Healthy Travel Media.

Wu, P.C.S., \& Wang, Y. (2011). The influences of electronic word-of-mouth message appeal and message source credibility on brand attitude. Asia Pacific Journal of Marketing and Logistics, 23(4), 448-472.

Yang, H. K. (2011). The impact of moving pharmaceutical products from prescription only to over-the-counter status on consumer exposure to advertising. International Journal of Human Ecology, 12(2), 1-12.

Ye, Q., Law, R., \& Gu, B. (2009). The impact of online user reviews on hotel room sales", International Journal of Hospitality Management, 28(1), 180-182.

Ye, Q., Law, R., Gu, B., \& Chen, W. (2011). The influence of user-generated content on traveler behavior: An empirical investigation on the effects of e-word-of-mouth to hotel online bookings. Computers in Human Behavior, 27, 634-639

Yeoh, E., Othman, K. \& Ahmad, H. (2015), Understanding medical tourists: Word-of-mouth and viral marketing as potent marketing tools, Tourism Management, 34,196-201. 


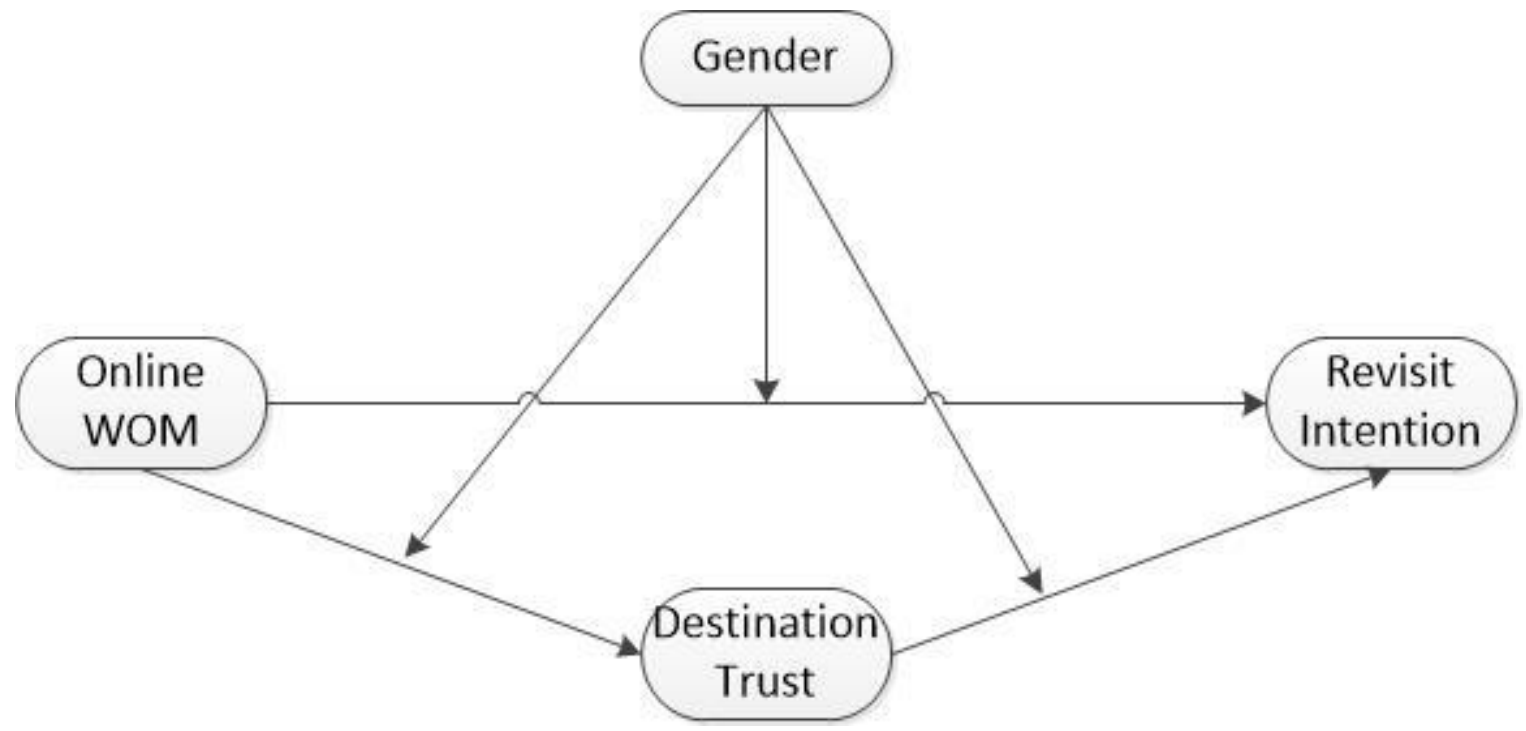

Figure 1: Conceptual model 
TABLE 1 Psychometrics Properties of the Measures $(n=240)$

eWOM

I often read other medical tourists' online travel reviews to know what destinations .53 make good impressions on others.

To make sure I choose the right medical destination, I often read other medical $\quad$.69 tourists' online travel reviews.

I often consult other medical tourists' online travel reviews to help me choose $\quad .99$ a good medical destination.

$3.40(1.26)$

$3.47(1.22)$

$3.39(1.18)$

$3.54(1.21)$ to a certain medical destination.

If I don't read tourists' online travel reviews when I travel to a medical destination, .96 I worry about my decision

When I travel to a medical destination, tourists' online travel reviews make me $\quad .97$ confident in travelling to the destination.

\section{Destination Trust}

Turkey as a medical destination meets my expectations.

I feel confidence with Turkish hospitals.

I will not be disappointed with Turkey's healthcare services.

Turkish hospitals guarantee satisfaction.

Turkish hospitals would be honest and sincere in addressing my concerns

I could rely on Turkish hospitals to solve my medical problems.

Turkish hospitals would make any effort to satisfy me.

Turkish hospitals would compensate me in some way in case of injuries after $\quad .96$ service

Intention to Revisit

I intend to revisit Turkey for medical attention in the near future.

I would like to visit Turkish hospitals more often.

Notes: CR, construct reliability; AVE, average variance extracted; $\alpha$, Cronbach's alpha; -* dropped items during confirmatory factor analysis. KMO Measure of Sampling Adequacy = .88; Bartlett's'Test of Sphericity $=7718, d f=120, p=.000$.

TABLE 2 Means, standard deviations (SD), and correlations of study variables

$\begin{array}{lllllllllllll}\text { Variables } & \text { Mean } & \text { SD } & \text { Mean } & \text { Mean } & \text { AVE } & \text { CR } & \alpha & 1 & 2 & 3\end{array}$
(Male) (Female)

$\begin{array}{lllllllllll}\text { 1. eWOM } & 3.44 & 1.04 & 3.32 & 3.54 & .67 & .92 & .93 & - & \\ \text { 2. Destination Trust } & 3.96 & 1.10 & 3.89 & 4.03 & .95 & .99 & .99 & .312^{* *} & - \\ \text { 3. Revisit intention } & 3.55 & 1.10 & 3.49 & 3.59 & .83 & .93 & .92 & .338^{* *} & .277^{* *}\end{array}$

Note: Composite scores for each variable were computed by averaging respective item scores; 
TABLE 3 Maximum likelihood estimates for the research model $(n=240)$

\begin{tabular}{|c|c|c|c|c|c|}
\hline $\begin{array}{l}\text { Exogenous } \\
\text { variables }\end{array}$ & $\begin{array}{l}\text { Endogenous } \\
\text { variables }\end{array}$ & $\begin{array}{l}\text { Coefficient } \\
\text { estimates }\end{array}$ & $\begin{array}{l}\text { Standard } \\
\text { error }\end{array}$ & $\begin{array}{l}\mathrm{t}- \\
\text { statistics }\end{array}$ & $p$ \\
\hline eWOM & Intention to Revisit & .296 & .067 & 4.42 & $* * *$ \\
\hline eWOM & Destination Trust & .332 & .065 & 5.08 & *** \\
\hline Destination Trust & Intention to Revisit & .190 & .063 & 3.02 & *** \\
\hline
\end{tabular}

TABLE 4: Standardized break down of the total effect of the research model $(n=240)$

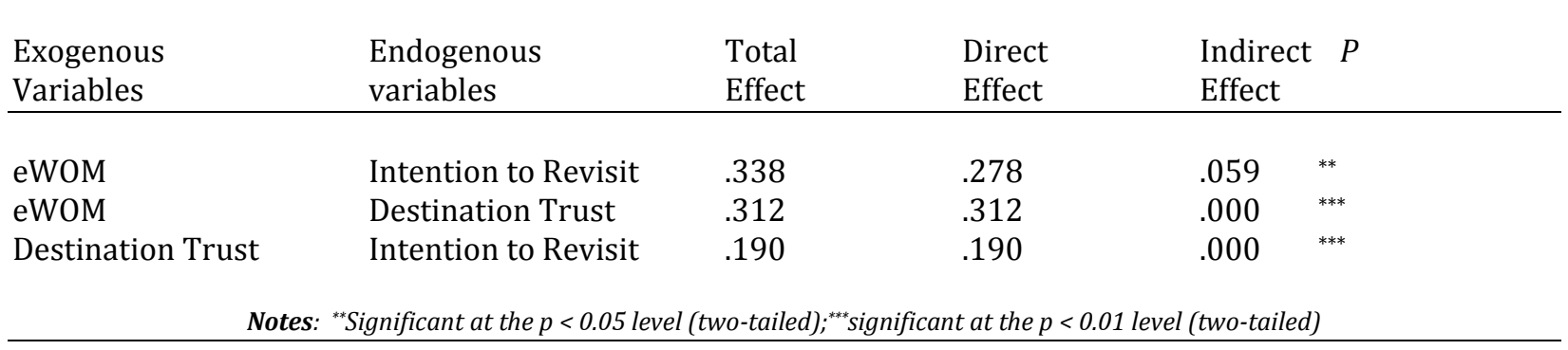

TABLE 5: Multi-group moderation analysis $(n=240)$

\begin{tabular}{lllll}
\hline $\begin{array}{l}\text { Exogenous } \\
\text { Variables }\end{array}$ & $\begin{array}{l}\text { Endogenous } \\
\text { variables }\end{array}$ & $\begin{array}{c}\text { Male }(\mathrm{n}=112) \\
\beta(t)\end{array}$ & $\begin{array}{c}\text { Female }(n=128) \\
\beta(t)\end{array}$ & Decision \\
\hline eWOM & $\rightarrow$ Intention to Revisit & $.363\left(3.56^{* * *}\right)$ & $.245(2.75)$ & Accepted \\
eWOM & $\rightarrow$ Destination Trust & $.372\left(3.86^{* *}\right)$ & $.293\left(3.25^{* *}\right)$ & Accepted \\
Destination Trust & $\rightarrow$ Intention to Revisit & $.120(1.28)$ & $.244\left(2.89^{* *}\right)$ & Accepted \\
\multicolumn{5}{c}{ Notes: ${ }^{* *}$ Significant at the $p<0.05$ level (two-tailed); $t \geq 1.960 ;{ }^{* * *}$ significant at the $p<0.001$ level (two-tailed); $t \geq 3.291$} \\
\hline
\end{tabular}

